\title{
The Risk Factor of Leprosy and The Care Process of Patient with Leprosy in Mahengetang Island of Sangihe: Qualitative Study
}

\author{
Yeanneke Liesbeth Tinungki, Detty Jeane Kalengkongan
}

Department of Health, Health State Politechnic of Nusa Utara, Indonesia

\begin{abstract}
Coresponding author: Yeanneke Liesbeth Tinungki, e-mail:yeanneketinungki82@gmail.com Co-author : Detty Jeane Kalengongan: e-mail: kalengkongandetty@gmail.com.

Submitted:26/03/2021 Revised: 09/05/2021 Accepted: 21/09/2021 Published online: 19/10/2021
\end{abstract}

DOI: https://doi.org/10.35308/j-kesmas.v7i2.3409 How to cite this article: Tinungki, L.T., \& Kalengkongan, D.J (2021). The Risk Factor of Leprosy and The Care Process of Patient with Leprosy in Mahengetang Island of Sangihe: Qualitative Study. J-Kesmas: Jurnal Fakultas Kesehatan Masyarakat (The Indonesian Journal of Public Health).8(2). 66-72.

\begin{abstract}
Leprosy is a chronic disease caused by Mycobacterium Leprae and can cause disability. Leprosy is a contagious disease from a medical perspective and extends social, economic, cultural, and social resilience issues. Mahengetang Island is one of the small islands in the Tatoareng District, Sangihe Islands Regency, with the highest leprosy cases in North Sulawesi Province. The research objective was to determine the risk factors for Leprosy and Care of leprosy patients in Mahengetang Tatoareng Island, Sangihe. The research method is a qualitative design with 13 informants who were interviewed. The participants are leprosy patients who undergo treatment and leprosy treatment which health workers supervise on Mahengetang Island. The research has been on for three months, from July to October 2020. The result showed that the risk factors for Leprosy were white spots (P1, P3, P5, P6), tasteless and cramps (P1, P2, P5, P10), thickened blackish skin (P2, P3, P4, P10, P12), itching and redness all over the body (P8). The result of research about leprosy patients are showed that one Participant took medication for six months (P1), seven participants took medication for one year, and five participants took the drug once. The conclusion is that the risk factors for Leprosy are white patches on the skin, tasteless and cramps, thickened black skin, itching, and redness all over the body. The care of Leprosy patients showed that all participants took Rifampicin with different periods depending on leprosy classification.
\end{abstract}

Keywords: Factors; Care; Leprosy; Mahengetang; Island

\section{Introduction}

Leprosy (Morbus Hansen) is a chronic disease caused by Mycobacterium leprae, which can cause disability. Leprosy is an infectious disease that causes complex problems, not only from a medical perspective, but extending to social, economic, cultural, security, and social resilience issues (National Institute of Allergy and Infectious Disease, 2011). Leprosy is a chronic infectious disease caused by breast-resistant bacteria, namely Mycobacterium leprae, which primarily attacks the peripheral nerves and secondarily attacks the skin and other organs (WHO, 2010). The cause of Leprosy is the Mycobacterium leprae bacteria. This type of Mycobacterium is an aerobic, non-sporeforming, rod-shaped membrane surrounded by a waxy cell membrane characteristic of the Mycobacterium species, measuring 1-8 cm micro and 0.2-0.5 micron wide. Usually in groups, and some are scattered one by one. Live in cells and are acid-resistant (BTA) (Chin, 2000).

Sangihe Island is a regency of the most northern districts and is directly adjacent to the Philippines Country with $736.98 \mathrm{~km}^{2}$ with 15 Districts, 22 Sub-
Districts, and 145 Villages with 1,454 inhabitants. This Regency Have 17 Primary Health Center and 1 Regional General Hospital (Health Profile of Sangihe Island, 2017). The prevalence of Leprosy in the Sangihe District in the last three years has increased. In 2019 Data from Sangihe Island District health Office patient of Leprosy 38 cases spread over 14 districts. One of the Districts in the Sangihe Island Regency is Tatoareng Districts. One of the villages is Mahengetang island Mahengetang, Tatoareng District, categorized as a highendemic village for Leprosy, namely as many as 22 people. On this island, there are 3 (three) Lindongan. Lindongan I has 61 houses with 71 families, 232 people. In Lindongan II, the number of houses is 53, the number of the family is 67 , and the number of people is 213 people. In Lindongan III, the number of houses is 60 , the number of families is 61 , and the number of people is 240. The total number of houses is 199 houses, number family of 208 families, and 685 people. A total of 454 people were examined for Leprosy, and 415 people got Prevention. There were six people with PB Positive and ten people with MB, so 16 people were treated. Those who did not receive prophylaxis were 17 people less than two years of age and five pregnant women. While treatment was less than two years, 47 
people, one person seriously ill, six people suspected of TB/Leprosy, working outside the area of 69 people, 92 people who have not been treated, and 22 people do chemo in the year so that there are 70 people left (Public health Office of Sangihe, 2020).

With the increase in leprosy cases, in 2019, the village/island of Mahengetang, Sangihe Regency, North Sulawesi Province is a demonstration project village (pilot) with a single dose of Rifampicin chemoprophylaxis as Leprosy Post Exposure Prophylaxis (LPEP), through the Ministry of Health's program of the Republic of Indonesia in the Prevention of Leprosy through Prevention (Waworuntu, 2019). Chemoprophylaxis in Mahengetang Island starts on 2729 March 2019. Those who do not receive chemo are pregnant women under two years old, suspected TB/Leprosy, kidney and liver disorder, seriously ill. While <2 years of RIF treatment. Dosage for 2-5 years $150 \mathrm{mg}, 5-10$ years $300 \mathrm{mg}, 10-15$ years $450 \mathrm{mg},>15$ years $600 \mathrm{mg}$. Data from the Sangihe Islands District Health Office implemented a leprosy eradication program on Mahengetang Island by providing chemoprophylaxis after seeing an increase in the spread of Leprosy on this island from 2019 to 2020, and the success of this program was re-evaluated in September 2020 (Public Health Office of Sangihe, 2020). According to data from the World Health Organization (WHO) 2016, the number of Leprosy worldwide in 2015 was 210, 758, and the highest was in Southeast Asia, namely 156. 118, followed by America with 28.806 and Africa with 20.004. Indonesia ranks third in the world with 17.202 cases (Astutik, 2016). In 2014 in Indonesia, 17.025 new cases of Leprosy were reported, with $83 \%$ of them being the Multi Basiler type (Ministerial RI Health, 2015).

Humans are the only host for the Mycobacterium leprae bacteria. Immune factors play a role in contracting Leprosy so that humans with low immunity will be easily infected. Low immunity, among others, can be influenced by physiological factors such as puberty, menopause, pregnancy, and factors of infection and malnutrition (Ministerial RI Health, 2012). Prevention and treatment of infectious diseases is part of the implementation of health development. To control infectious diseases, it must be carried out in an integrated manner with other health efforts, namely efforts to prevent, cure, and recover. This is because the spread can occur quickly, either through movement, direct contact or because of the type of disease itself (Ministerial RI health, 2019). Seeing the above phenomena, it appears that the problems of patients with Leprosy are many and complex. Studies in various areas and the Sangihe Islands District have revealed a lot about the problems of patients with Leprosy. This study reveals a phenomenon focused on the risk factors for Leprosy and its treatment using a phenomenological qualitative approach where it is expected that comprehensive information related to the above phenomena will be obtained. The research objective was to determine the risk factors for Leprosy and the treatment or Care Process of leprosy patients in Mahengetang Island, Tatoareng District.

\section{Methods}

The research method used is a qualitative method with an in-depth interview research type. This research has been ongoing for approximately three months, namely July to October 2020. This research was conducted at the Participant's house on Mahengetang Island, tatoareng District. Methods of data collection using inclusion criteria include leprosy patients diagnosed with Leprosy and close contact with patients willing to become participants. Analysis of Data using Colaizzi analysis was carried out in seven stages, namely, playing back the recorded results, this transcript was tested for accuracy by listening to the recording again, the results of the field notes were in the form of a non-verbal response, after repeatedly reading the researcher determined the statements with the phenomenon being studied according to the objective. In research, if there are the repetition of statements that contain the same or nearly the same meaning as the transcript of the information, the keywords are identified through the filtering of these statements, and the determination of categories is carried out very carefully so that there is no deviation from the meaning of the participants. The technique of sampling used the purposive sampling technique. The principle of data validity in this study uses the triangulation method.

\section{Results}

\section{Characteristics of Participant}

The target participant is 13 (thirteen) leprosy patients. In general, the Participant based on gender consisted of 4 men and nine women, all of whom came from Mahengetang Island, all of whom were from the Sangihe tribe. The classification of Leprosy in Mahengetang Island is classified as the PB classification is participant $1(\mathrm{P} 1)$ and those classified as MB are 12 people is Participant 2 (P2), Participant 3 (P3), Participant 4 (P4), Participant 5 (P5), Participant 6 (P6), Participant 7 (P7), Participant 8 (P8), Participant 9 (P9), Participant 10 (P10), Participant 11 (P11), Participant 12 (P12), Participant 13 (P13). 
Table 1. The Participant Distribution Based on Characteristics

\begin{tabular}{lllll}
\hline \multicolumn{1}{c}{ Name } & A & Religion & Education & Profession \\
& ge & & & \\
\hline Participant 1 & 45 & Cr. & Primary & Fisherman \\
(Tn. R.T) & yo & Protestant & School & \\
Participant 2 & 36 & Cr. & Primary & Housewife \\
(Ny. L.L) & yo & Protestant & School & \\
Participant 3 & 55 & Cr. & Primary & Housewife \\
(Ny. S.D) & yo & Protestant & School & \\
Participant 4 & 19 & Cr. & Senior High & Not yet \\
(Na. N.P) & yo & Protestant & School & working \\
Participant 5 & 48 & Cr. & Junior High & Housewife \\
( Ny. L.T) & yo & Protestant & School & \\
Participant 6 & 54 & Cr. & Primary & Fisherman \\
( Tn. E.U) & yo & Protestant & School & \\
Participant 7 & 54 & Cr. & Primary & Housewife \\
( Ny. T.T) & yo & Protestant & School & \\
Participant 8 & 69 & Cr. & Junior High & Housewife \\
(Ny. K. T) & yo & Protestant & School & \\
Participant 9 & 32 & Cr. & Junior High & Housewife \\
(Ny. F.B) & yo & Protestant & School & \\
Participant & 63 & Cr. & Primary & Fisherman \\
10( Tn. & yo & Protestant & School & \\
M.L) & & & & \\
Participant & 60 & Cr. & Primary & Housewife \\
11( Ny. & yo & Protestant & School & \\
A.M) & & & & \\
Participant & 39 & Cr. & Junior High & Fisherman \\
12 (Tn. & yo & Protestant & School & \\
W.J) & & & & \\
Participant & 41 & Cr. & Primary & Housewife \\
13 (Na. & yo & Protestant & School & \\
M.S) & & & & \\
\hline Characteristics & & \\
\hline
\end{tabular}

(Characteristics of a leprosy patient, 2020)

Based on table 1, the characteristics of leprosy sufferers based on the ages of all participants ranged from 19 years to 69 years with different education levels and different types of work. Everything participant adheres to Christian Protestant. Thirteen Participants found that most had low education as many as eleven $(85 \%)$ participants. P1, P6, P10, P12 were fishermen, while the P2, P3, P5, P7, P8, P9, P11, and P13 were domestic workers. One Participant has not worked because he is 19 years old. All participants have occupations with an income below the Average Minimum Wage. The amount of participant income ranges from 500,000 to 2.000 .000 /month. This shows 7 participants whose income is far from the Average Minimum Wage, but some also have excess income. Although some participants had excess income, most participants complained that they could not make ends meet every day. The following is the Participant's statement:

Table 2. The Participant Distribution Based on occupations below the Average Minimum Wage

\begin{tabular}{ll}
\hline Participants & \multicolumn{1}{c}{ Statement } \\
\hline P1 & "Income is uncertain. Rp. 300.000/ month \\
& $\begin{array}{l}\text { is sometimes not enough to meet family } \\
\text { needs." }\end{array}$
\end{tabular}

$\mathrm{P} 2$

"Income is uncertain. Rp. 300.000/ month is sometimes not enough to meet family needs."

"There is no income. It is still a parents' responsibility. Ask parents"

"Income is uncertain. Cannot meet the needs of the family."

P7

"Income is uncertain. Sufficient"

P11

"Income > 500.000/month. Not sufficient"

$\mathrm{P} 13$

"Uncertain. Not enough"

(Characteristics of a leprosy patient, 2020)

Participant's income is partly below the Regional Minimum Wage, which is as much as 7 (54\%) of participants.

\section{The Risk Factor of Leprosy}

\section{Early Symptoms of Leprosy patient}

The Participant's statement about the initial symptoms that appear inpatient. Following is the Participant's statement:

"Early symptoms such as phlegm/white spots on the back of the body" (P1).

"On the right side, you do not feel and feel cramps. The skin is thickened brackish "(P2).

"The initial symptom is thought black and tasteless area of the left leg. Then appear white spots during treatment until now" (P3).

"The black spots on the face are very thick. Symptoms have appeared since 2016 "(P4).

"The white spots on the left calf and the right arm have been tasteless for about five years "(P5).

"The first symptoms appear in the form of white spots like tinea versicolor on the body, chest, and back " (P6).

"First appears itching, redness occurs all over the body, especially the back area. According to the allergy doctor. Then given Dexamethasone. But the drug runs out over and over again "(P8).

"Symptoms appear first in the right leg and left leg than feel cramps "(P10).

"Blackish skin" (P12).

The results showed that the risk factors for Leprosy were white patches (P1, P3, P5, P6), tasteless and cramps (P1, P2, P5, P10), thickened black skin (P2, P3, P4, P10, P12), itching and redness all over the body (P8). 


\section{Participants opinion about the causes of Leprosy}

"Cause does not know"(P1).

"Do not know" (P2).

"Not knowing the causes of leprosy" (P3).

"Do not know" (P4).

"Do not know" (P5).

"Unknown" (P6).

"Do not know" "(P7).

"Unknown disease" (P8).

"Do not know "(P9).

"Unknown "(P10).

"Do not know" (P11).

"Do not know anything "(P12).

"Do not know" (P13).

All participants do not know the cause of Leprosy.

\section{The Care of Leprosy patients}

The patient's feeling about the Experience while treating leprosy

"The first examination by the health team in 2018 was shocked to hear that it was discovered that this is leprosy" (P1).

"Feeling of fear because this is the first time knowing you have leprosy" (P2).

"The mind becomes afraid "(P3).

"The first feeling of embarrassment "(P4).

"Feelings of fear" (P5).

"I was shocked to hear. Just want to get well" (P6).

"Worry can catch-all" (P7).

"Feeling afraid after knowing that leprosy" (P8).

"Feelings of shock" (P9).

"Feelings of fear" (P10).

"Feeling of fear" (P11).

"I was surprised that I did not expect to have leprosy" (P12).

"Fear" (P13).

Four participants (P1, P6, P9, P12) expressed that they were shocked to hear that they had Leprosy. Eight participants expressed their feelings of fear that they had Leprosy (P2, P3, P5, P7, P8, P10,

P11, P13). Moreover, one Participant (P4) expressed embarrassment because his face was damaged and thick black.

\section{The Experience during care of Leprosy}

"One medicinal paper is taken for one month for six months. If you take medicine, the germs are gone, but the urine is red" (P1).

"Once I take six medicinal seeds. After that, both two drugs for up to 1 month. One paper one month to one year. The medicine is red. The officer said, do not be afraid of difficulties when taking the first six seeds.
Then the pee is red" (P2).

"2014-2015 is still unclear. Treatment starts in 2017 for a year. Run out of medicine in September 2018. Three years in Bitung, there are white spots, and they can scald with hot water. Tasteless skin. The body feels hot because for a year there are no dropouts"(P3).

"Drinking red medicine for one year. The difficulty is body aches and headaches" (P4).

"I took medicine for the first time in 2017. I first got Leprosy before my husband. One year of taking the medication without breaking. August 2018 finished taking medicine. The difficulty with taking medication is that the nails turn blue for two months after two months the blueness disappears" (P5).

"There is no difficulty taking medicine. Take medicine for one year. Starting February 2019, it will be finished in February 2020. No complaints" (P6).

"I took medicine for a month. Because the husband has leprosy, the officer said he had to drink. No complaints" (P7).

"I was in bed for three months because I could not get out of bed: the whole body aches, pains, heat. Take MDT MB Adult MDT-Combi-Rifampicin for one year from January 2019 to January 2020. There is no difficulty when taking medication if pee is orange" (P8).

"I have trouble taking medicine. Take boasting medicine March to February 2020. But still obey until it is finished" (P9).

"Take prophylactic medicine once. Red urine" (P10).

"Taking medication since the first prophylaxis" (P11).

"Take the medicine once. His name is Rifampicin"(P12).

"Take the prophylactic drug once, namely Rifampicin" (P13).

The results showed that one Participant took the drug for six month P1, seven participants took medication for one year and five participants took the drug once.

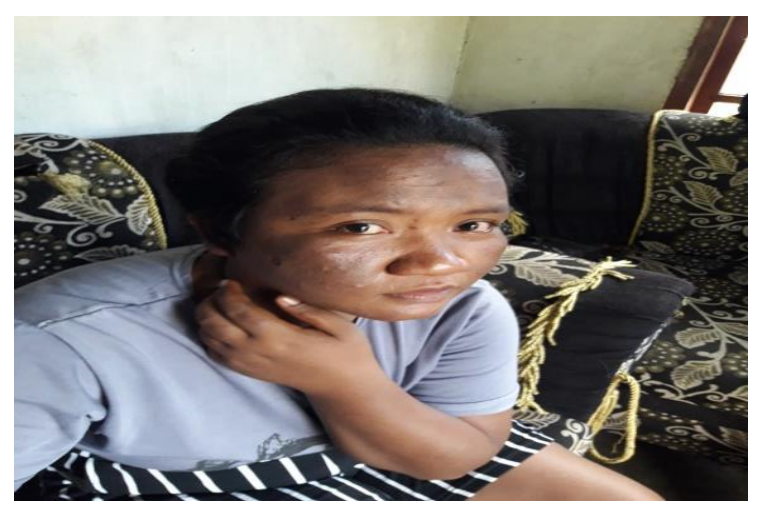

Figure 1. Patient of Leprosy 


\section{Discussion}

\section{Characteristics of Participant}

Characteristics of leprosy sufferers based on the ages of all participants ranged from 19 years to 69 years with different education levels and different types of work. The prevalence of Leprosy by age group does not reflect the risk of specific age groups to develop the disease. Leprosy occurs at all ages ranging from infants to the elderly ( 3 weeks to more than 70 years). However, the highest proportion is above 5\%, indicating high transmission in the local area (Ministerial RI Health, 2011). Thirteen Participants found that most had low education as many as eleven (85\%) participants. P1, P6, P10, P12 were fishermen, while the $\mathrm{P} 2, \mathrm{P} 3, \mathrm{P} 5, \mathrm{P} 7, \mathrm{P} 8, \mathrm{P} 9, \mathrm{P} 11$, and $\mathrm{P} 13$ were domestic workers. One Participant has not worked because he is 19 years old. The result of this study is in line with the result of Herawati's (2019) study regarding self-care as a risk factor for disability in leprosy patients. That of the 35 respondents, it was found that most of them had low education as much as $23(65.7 \%)$. The high proportion of lepers with low education result in a low healthy lifestyle. Low education is one of the risk factors for disability in people with Leprosy, although this effect is still not clearly understood.

Education is one of the factors determining the level of a person's knowledge; if a person's knowledge of disease is high, the individual will try to heal himself and prevent a disease against himself (Laili, 2018). Educational status affects the treatment of leprosy patients. The lower the level of education, the slower the disbursement of treatment will be so that the disability will worsen (Petter and Eshiet, 2002 in Herawati 2019). The low education level of persons affected by Leprosy has a profound impact on work. The thriving Participant's income is partly below the Regional Minimum Wage, which is as much as 7 (54\%) of participants. This is in line with Herawati's research (2019) that most people with Leprosy have an income $<$ Regional Minimum Wage $(77,1 \%)$, and there is a relationship between income and the incidence of level II disabilities. Socio-economy has a relationship with physical disabilities in people with Leprosy. According to WHO, about $90 \%$ of people affected by leprosy attack weak or poor socioeconomic groups. Low socioeconomic conditions will lead to high occupancy density, poor environment, and limited ability to buy food for daily needs, causing malnutrition (Husen et al., 2017). The low income of people with Leprosy can affect the ability to get services, and health care will be minimal. It increases the risk of having a level II disability greater than those with higher incomes (Herawati, 2019).

\section{The Risk Factor of Leprosy}

\section{Early Symptoms of Leprosy patient}

The clinical manifestations (signs and symptoms) of Leprosy are; a) The presence of single or multiple lesions, usually less pigmented, b) The initial signs are whitish spots with sometimes unclear borders and begin or have numbness in the area of the spots, c) Heat from low degrees to shivering, d) Anorexia, nausea, cephalgia, sometimes accompanied by irritation, neuritis. In addition, there are presumptive signs that cannot be used as the basis for a person being declared Leprosy. These signs are red/white skin patches, nonitchy patches, shiny or dry, noisy skin, skin disorders such as not sweating or hairless, wounds that are difficult to heal, tenderness in nerves, weakness of limbs or face, and a tingling feeling, such as stabbing and pain in the limbs. To determine a diagnosis of Leprosy, it is necessary to have cardinal signs, namely: a) numb skin disorders. Skin disorders or lesions can take hypopigmentation (white spots) or anesthesia (numbness) on the skin. b) Thickening of the peripheral nerves accompanied by chronic disruption of the function of the peripheral nerves. These disturbances can be in sensory dysfunction characterized by numbness, motor function disorders characterized by muscle weakness/paralysis, and autonomic function disorders characterized by dry and cracked skin. Laboratory examination results from skin tissue scrapings showed positive smear (MOH RI, 2012).

Based on the above symptoms, the Sangihe Islands District Health Office in 2019 carried out a leprosy examination. Total leprosy examinations on Mahengetang Island totaled 454 people and received 415 prevention. There were six people with $\mathrm{PB}$ positive and ten people with $\mathrm{MB}$, so 16 people were treated. Leprosy germs have an incubation period of 2-5 years and can even take more than five years (Ministerial RI Health, 2015). Leprosy is a dreadful disease and is feared because of the ulceration, mutilation, and deformity that it causes, causing social, psychological, and economic problems. There are two types of Leprosy, namely Paucibasillary (PB) and Multibacillary (MB). The source of transmission of Leprosy is type $\mathrm{MB}$, leprosy sufferers. Leprosy is transmitted through direct contact through the skin and respiratory tract repeatedly and over a long period (Kosasih, 2001). Lack of public awareness to improve health and prevent Leprosy is supported by low education to treat Leprosy. According to researchers, in Mahengetang Island, the most significant number of patients are Multibaciller patients, so the possibility of new cases will be even greater. 


\section{Participants opinion about the causes of Leprosy}

All participants do not know the cause of Leprosy. This is following Siregar's 2018 research on the Experience of families caring for people with Leprosy in facing the stigma of the community in Limo Depok, West Java. Nine participants answered the sub-themes and main themes. The nine participants said they did not know what Leprosy was.

\section{The Leprosy Patient Care}

\section{The patient's feelings about the Experience while treating Leprosy}

Four participants expressed that they were shocked to hear that they had Leprosy. Eight participants expressed their feelings of fear that they had Leprosy. Stigma can be reduced by taking various steps. Sermrittirong (2014, Andhikari (2013), Raffery Floyd Richard, and Gurungu (2000) suggest that steps to reduce community stigma against people affected by Leprosy are only by providing health education about Leprosy.

Health education or health promotion is carried out to provide information about early signs and symptoms of Leprosy and technical activities to combat Leprosy. This information can be in the form of guidelines, technical instructions, leaflets, posters, flipcharts, banners, banner, counseling and other, influencing individuals, families, and communities to eliminate stigma and eliminate discrimination against leprosy sufferers and people who have had Leprosy, influencing relevant stakeholders to obtain support for leprosy control policies, in particular the elimination of stigma and discrimination, as well as financing that can be done and assist individuals, families, and communities to play an active role in the discovery and management of Leprosy, implementing chemoprophylaxis, and research and development activities (Ministerial RI Health, 2019).

\section{The Experience during care of Leprosy}

The result showed that one Participant took drg for six months, seven participants took medication for one year, and five participants took the drug once.

This follows Siregar's research (2017) with the research title on family experiences of caring for people with Leprosy in facing Community Stigma in Limo Depok West Java Village. Nine participants said the treatment process in preventing Leprosy was complying with taking the medication provided by the Puskesmas. Leprosy prevention is to achieve PR (prevalence rate) of less than 10.000 people in all districts/cities and the continuity of the leprosy program in all regions. This is pursued through early detection of leprosy cases and treatment with MDT, preventing disability, transforming the wider community, and ensuring the availability and quality of drugs. In addition, to increase public awareness and all stakeholders in helping prevent disability due to Leprosy (Ministerial RI Health, 2011). Chemotherapy for Leprosy started in 1949 with DDS as a single drug (DDS monotherapy). DDS should be taken for 3-5 years for PB, while MB 510 years, even for life. The drawbacks of DDS monotherapy are resistance, the emergence of persister bacteria, and the occurrence of defaulter patients. In 1964 resistance to DDS was discovered. Therefore, in 1982 WHO-recommended treatment with Multi-Drug Therapy (MDT) for PB and MB types. The MDT treatment regimen in Indonesia is as recommended by WHO.

The results of research on leprosy treatment by administering drugs are following WHO recommendations. Chemoprophylaxis for Leprosy is carried out one time. It can be repeated after two years from the previous provision if new leprosy sufferers are found between household contacts/neighbor contacts/ social contact. Chemoprophylaxis for Leprosy given by health workers must be taken directly in front of the officer at the time of administration. Determination of the target population to be given chemoprophylaxis for Leprosy according to the method determined by the local government. The leprosy chemoprophylaxis is adjusted to the situation and conditions of the target area. Type PB treatment is given a dose based on age group. Rifampin aged > 15 years $600 \mathrm{mg} / \mathrm{month}$ is taken in front of the officer. Giving one blister for 28 days takes six blisters that can be drunk for 6-9 months. For patients with multibacillary type (MB) leprosy type $\mathrm{MB}$, treatment is given a dose based on the age group Rifampin aged > 15 years $600 \mathrm{mg} / \mathrm{month}$. Giving one blister for 28 days takes 12 blisters to be drunk for 1218 months. For the Prevention of Leprosy through education about Leprosy, especially in endemic areas, and conducting early diagnosis and treatment to prevent transmission (Ministerial RI Health, 2019).

\section{Conclusion}

The conclusion of the research on the risk factors for Leprosy and the treatment of leprosy patients in Mahengetang Island, Tatoareng District, shows that the risk factors for Leprosy are the presence of white patches on the skin, tasteless and cramps, thickened black skin, itching, and redness of the whole body. The treatment of leprosy patients showed that all participants took the drug Rifampicin. One Participant took medication for six months, seven participants took medication for one year, and five Participants took prophylactic drugs once a year. 


\section{Acknowledgment}

For the community, the result of this study can be used as a source of information and material for consideration to improve health, especially Leprosy further. Moreover, for the research institution, this research can be used as a source of information and valuable to reduce the incidence of Leprosy in Mahengetang Island and surrounding areas and provide an overview of treatment of leprosy patients Mahengetang island, Tatoareng.

\section{References}

Astutik, E \& Kiptiyah,N,M. (2016). Factors related to the Self-Care Behavior of Ex-LeLepers in the Technical Implementation Unit for Social Rehabilitation of Ex- Persons with Leprosy in Nganget Tuban, East Java.Indonesian. Journal of health Epidemiology.

1(1). http://dx.doi.org/10.21111/jihoh.v4i1.3437

Cin, J. (2000). Control of Communicable Disease Manual edition 17. American Public Health Association. Washington

Health Office Data (2020). Data from the Sangihe Islands District Health Office. Dinkes Kepulauan Sangihe.

Health Profile of Sangihe Islands District. (2017). http://www. Kemkes.go.id accessed 28 Oct 2020

Health Office (2020). Profile of the Health Office in 2018. Dinkes Kepulauan Sangihe.

Herawati, C. (2019). Self-care as a risk factor for disability in people with Leprosy. Indonesia Public Health Journal. 14(1). http://dx.doi.org/10.20473/ijph.v12i1.2017.13-26

Husein, S,H., Muhannad,R. (2017). Factors related to the incidence of disability in leprosy patients in the working area of the Kalumata health center, South Ternate City. Journal of Health Research. 6(2). https://ejournal.poltekkes.smg.ac.id lois/index.php/ irk

Leprosy Control program. (2020). Directorate General of Disease Control and Environmental health. Jakarta. https://www. Joglabang.com.

Ministerial RI health. (2011). Ministrerial Decree RI health. About the Guidelines Preparation of Health Human Resouces Planning at Provincial., District, and Hospital Levels. National Guidelines

Ministerial RI Health. (2012). National Guidelines Leprosy Control program. Jakarta: Directorate General of Disease Control and Environmental Health. https://www/joglabang.com.

Ministerial RI Health. (2016). National Guidelines Leprosy Control Program. Jakarta

Ministerial RI Health. (2018). Indonesia health profile 2015 sat data and informes ditjenP2P (kemenkes) https://www.kemenkeu.go.id.

Ministerial RI Health. (2019). Ministerial Regulation Health oh the Republic of Indonesia Number 11 of 2019. Regarding the Prevention of Leprosy. https:www.kemenkes.go.id

National Institute of Allergy and Infectious Disease. Leprosy (Internet). U.S: Department of Health and Human Services: 2011 (cited 2011, December). http://www.niaid.nih.gov/topics/leprosy/understan ding/pages/whatis.aspx

Moh RI (2012). National Guidebook for the Eradication of Leprosy. Printed XVIII. Directorate General of Disease Control and Environmental Health

Siregar, T.,Ratnawati,D. (2018). Family experiences of caring for people with Leprosy face Community Stigma in Limo Village, Depok, West Java. Indonesian Nursing Scientific Journal. 1(2). http://www.journal.umt.ac.id/index.php.jik

Waworuntu. (2019). Chemoprophylaxis as Leprosy Post Exposure Prophylaxis Able to Reduce New Cases of Leprosy.P2P. RI Ministry of health, Directorate general Disease Control Prevention.

Word Health Organization. (2010). Information. Center for Data and Information of the Ministry of the health of the Republic of Indonesia

Word Health Organization. (2016). Leprosy Fact Sheet.www.who.int,Leprosy. Genewa. 